\title{
Identification of $\gamma$-Aminobutyric Acid (GABA) in Loloh as A Potential Drink as Antihipertension
}

\author{
Identifikasi Asam $\gamma$-Aminobutirat pada Loloh Sembung Sebagai Minuman \\ Fungsional yang Berpotensi Sebagai Antihipertensi
}

\author{
I Gusti Ayu Wita Kusumawati*, Ni Made Indri Sugiantari'1, I Gede Ariyasa1, Ida Bagus Agung \\ Yogeswara ${ }^{1,2}$ \\ 1* Program Studi Ilmu Gizi, Fakultas Ilmu Kesehatan Sains dan Teknologi, Universitas Dhyana Pura, Bali. \\ 2 Department of Food Science and Technology, University of Natural Resources and Applied Life Sciences \\ Bodenkultur, Vienna, Austria
}

\begin{abstract}
Loloh sembung (Blumea balsamifera) is a functional drink that is widely consumed by Balinesse people and exhibit health-promoting effect. The purpose of this study was to identify GABA of loloh sembung which has physiological effect as antihypertensive. Proximate analysis was performed to determine nutritional value content of loloh sembung. Atomic Absorption Spectrophotometric (AAS) method was employed to determine potassium and sodium content, and identificatio of $\gamma$-aminobutyric acid (GABA) using Thin Layer Chromatography (TLC) method. In this study, water content of loloh sembung was $99.2324 \%$, ash 0.0117. Fresh sembung leaves have water content $83.8112 \%$, ash content $2.0617 \%$, protein $0.9659 \%$, fat 2.850\%, and carbohydrate 10.3109\%. Loloh sembung contained sodium, $51.65 \mathrm{mg} / \mathrm{L}$ and potassium 1353.10 $\mathrm{mg} / \mathrm{L}$. Subsequently, fresh sembung leaves contained sodium $579.72 \mathrm{mg} / \mathrm{L}$ and pottasium $1353.19 \mathrm{mg} / \mathrm{L}$ respectively. In this study, GABA was detected in loloh sembung and has promising prospect as antihypertensive-functional drink.
\end{abstract}

Key word : Loloh sembung, functional drink, GABA, antihypertensive, TLC

\begin{abstract}
ABSTRAK
Loloh sembung (Blumea balsamifera) merupakan minuman fungsional yang sering dikonsumsi oleh masyarakat Bali serta memiliki efek kesehatan. Tujuan dari penelitian ini adalah untuk mengidentifikasi GABA pada loloh sembung yang berpotensi sebagai antihipertensi. Analisis yang dilakukan meliputi analisis proksimat untuk mengetahui kandungan nilai gizi, analisis kandungan natrium kalium dengan menggunakan metode Spektrofotometris Serapan Atom (SSA), dan identifikasi Asam r-aminobutirat (GABA) dengan menggunakan metode Thin Layer Chromatography (TLC). Pada penelitian ini didapatkan hasil proksimat loloh sembung, kadar air 99,2324\%, kadar abu 0,0117\%. Daun sembung memiliki kadar air 83,8112 \%, kadar abu 2,0617\%, protein 0,9659 \%, lemak 2,850\% dan karbohidrat 10,3109 \%. Hasil kandungan natrium loloh sembung $51,65 \mathrm{mg} / \mathrm{L}$ kalium $1353,10 \mathrm{mg} / \mathrm{L}$, sedangkan pada daun sembung kandungan natrium sebesar 579,72 mg/L dan kalium 1353,19 mg/L. Pada hasil penelitian inni terdapat kandungan GABA dalam loloh sembung sehingga berpotensi dapat digunakan sebagai minuman fungsional antihipertensi.
\end{abstract}

Kata Kunci : Loloh sembung, minuman fungsional, GABA, antihipertensi, TLC

\section{PENDAHULUAN}

Hipertensi adalah suatu keadaan ketika tekanan darah di pembuluh darah meningkat secara kronis. Hal tersebut dapat terjadi karena jantung bekerja lebih keras memompa darah untuk memenuhi kebutuhan oksigen dan nutrisi tubuh (Riskesdas,2013). Seseorang dapat

\footnotetext{
*Corresponding author : I Gusti Ayu Wita K
}

Email : witakusumawati@undhirabali.ac.id dikatakan hipertensi apabila tekanan darah sistolik $\geq 140 \mathrm{mmHg}$ atau pengukuran darah diastolik $\geq 90 \mathrm{mmHg}$ menurut kriteria Joint National Committee (JNC) VII (2003). Prevalensi hipertensi diagnosis oleh tenaga kesehatan berdasarkan wawancara tahun 2013 (9,5\%) lebih tinggi dibandingkan dengan tahun 2007 $(7,6 \%)$. Saat ini banyak dikembangkan minuman fungsional yang diperkaya/mengandung komponen bioaktif tertentu yang berpotensi 
digunakan untuk antihipertensi, salah satunya yakni komponen bioaktif asam $\gamma$-aminobutirat (GABA).

Asam $\gamma$-aminobutirat (GABA) adalah asam amino yang memiliki empat atom karbon yang berfungsi sebagai neurotransmitter penghambat utama dalam sistem saraf pusat (Kimura et al., 2002). GABA mempunyai peranan yang penting dalam kedua kontrol sistem saraf pusat dan perifer dari tekanan darah (Kimura et al, 2002 ; Hayakawa et al., 2005). GABA terdapat dalam berbagai tanaman dan makanan fermentasi seperti daun teh (Abe et al., 1995), produk susu fermentasi (Hayakawa et al., 2004), tempe (Aoki et al., 2003) , kecap (Yamakoshi et al., 2007), bijibijian padi (Akama et al., 2009) dan tomat (Yoshimura et al., 2010). Pemberian makanan yang mengandung GABA atau yang diperkaya dengan GABA seperti teh hijau, produk susu fermentasi dan kecap selama 4-6 minggu dapat menekan peningkatan tekanan darah sistolik pada tikus hipertensi spontan (Abe et al, 1995;. Hayakawa et al, 2004;. Yamakoshi et al, 2007). GABA dapat menghambat pelepasan nonadrenalin oleh sistem saraf pusat (Hayakawa et al., 2002). Keberadaan GABA pada tumbuhan pertama kali diketahui pada umbi kentang. Penelitian selanjutnya dilaporkan juga bahwa GABA diketahui terdeteksi pada buah Solanum lycopersicum dan beras hitam (Akihiro et al., 2008). Meskipun demikian, masih banyak tumbuhan yang belum diteliti dalam aspek deteksi GABA. Salah satunya adalah daun sembung. Daun sembung (Blumeae balsamifera) adalah salah satu tanaman obat tradisional yang memiliki berbagai khasiat untuk kesehatan. Di Bali daun sembung sering dimanfaatkan dan dikonsumsi dalam bentuk loloh. Loloh adalah campuran beberapa tanaman obat yang dikonsumsi dengan cara diminum (Nathalie, 2009).

Minuman fungsional merupakan salah satu alternatif yang banyak dicari dan dikonsumsi oleh masyarakat. Daun sembung bisa diolah menjadi minuman siap konsumsi berupa loloh. Minuman siap konsumsi yang dapat menghemat waktu tanpa mengabaikan rasa dan asupan gizi yang dibutuhkan (Endrizzi et al., 2009). Minuman fungsional adalah salah satu produk siap konsumsi yang banyak dikembangkan. Minuman fungsional merupakan produk minuman non alkohol, yang dapat berupa minuman berenergi, minuman herbal, jus dan berbagai minuman yang diperkaya dengan zat gizi dan non gizi yang bermanfaat meningkatkan kesehatan (Duyff, 2012). Loloh sembung mengandung antioksidan yang dapat menangkal radikal bebas (Wita et al.,
2016). Loloh sembung juga mengandung senyawa fenolik dan flavonoid yang tinggi (Wita et al., 2016). Flavoniod yang terkandung dalam ekstrak menunjukkan terdapatnya aktivitas antioksidan dan antikanker (Bae et al., 2012). Belum ada penelitian tentang GABA yang berasal dari loloh sembung oleh karena itu peneliti tertarik melakukan penelitian mengenai identifikasi GABA pada loloh sembung sebagai minuman fungsional yang berpotensi sebagai antihipertensi, selain itu peneliti juga ingin mengidentifikasi kandungan GABA dalam daun sembung segar, sehingga bisa diketahui antara daun sembung segar dan yang sudah diolah mengandung GABA atau tidak memiliki kandungan GABA.

\section{METODE PENELITIAN \\ Bahan dan Alat}

Penelitian ini menggunakan metode rancangan acak lengkap. Sampel daun sembung yang digunakan berasal dari daun segar dan daun yang dikeringkan untuk pembuatan loloh sembung dengan formulasi 7\% . Pembuatan loloh sembung dalam penelitian ini menggunakan proses perebusan selama 7 menit dan sampel daun segar diekstrak edengan menggunakan air. Kemudian sampel loloh sembung dan daun sembung yang telah diekstrak dilakukan identifikasi GABA dengan menggunakan metode TLC.

Sampel daun sembung (Blumea balsamifera) yang digunakan dalam penelitian dipetik pada bulan April 2017, berasal dari Desa Darmasaba, Badung, Bali. Standar GABA (SigmaAldrich), akuades, nihidrin, n-butanol, asam asetat glasial. Plat silika, chamber, pinset, oven, timbangan digital, scanner TLC 4 (CAMAG), TLC visualizer (CAMAG), pipet $5 \mu \mathrm{l}$.

\section{Metode}

Pembuatan Tahap pertama dalam penelitian ini pembuatan ekstrak daun sembung dan pembuatan loloh sembung. Pembuatan loloh sembung diawali dengan memetik daun sembung segar, dibersihkan dengan cara dicuci, ditiriskan lalu ditimbang. Kemudian daun yang telah ditimbang dikeringkan. Proses pengeringan dilakukan tanpa terkena sinar matahari langsung selama 15 hari pada suhu \pm , dilakukan penimbangan sampel kering daun sembung. Tahap selanjutnya daun sembung kering diblender (miyako), dan diayak dengan menggunakan ayakan 80 mesh sehingga didapatkan sampel dalam bentuk serbuk. Kemudian dilakukan ekstraksi. 


\section{Metode Ekstraksi \\ Perebusan}

Sebanyak $7 \mathrm{~g}$ sampel serbuk daun sembung diekstraksi dengan menambahkan $100 \mathrm{ml}$ akuades kemudian direbus selama 7 menit. Kemudian air hasil rebusan disaring dengan menggunakan kertas whatman ke dalam erlenmeyer. Selanjutnya dilakukan identifikasi GABA dalam loloh sembung dengan menggunakan metode TLC.

\section{Identifikasi GABA dengan metode TLC (Qiu et al., 2009)}

Plat silika dipotong dengan ukuran 10 x10 cm. Plat dicuci dengan menggunakan $10 \mathrm{ml}$ metanol. Kemudian plat silika dioven selama \pm 30 menit pada suhu 1000 C. Siapkan sampel loloh sembung dan daun sembung segar yang telah diekstraksi. Timbang $10 \mathrm{mg}$ standar GABA masukkan ke dalam labu ukur $10 \mathrm{ml}$, kemudian masukkan $5 \mathrm{ml}$ air. Siapkan fase gerak yang akan digunakan yang terdiri dari n-butanol, asam asetat glasial, air dan nihidrin dengan perbandingan 5:3:2, masukan ke dalam labu ukur $100 \mathrm{ml}$. Selanjutnya dipipet 1,5 ml standar GABA, loloh sembung, dan ekstrak daun sembung segar tempatkan pada masing-masing tabung. Masukkan kedalam TLC otomatis (Automatic TLC 4)/totol manual dengan menggunakan pipet $5 \mu \mathrm{l}$. Plat dikeringkan, kemudian dimasukkan ke dalam chamber yang berisi fase fase gerak. setelah \pm 1 jam plat dimasukkan ke dalam scanner TLC 4.

\section{HASIL DAN PEMBAHASAN \\ Preparasi Loloh Sembung}

Rendemen yang didapatkan dari pengeringan daun sembung segar sebesar 11,5\%. Daun sembung kering diamati secara fisik memiliki warna abu-abu kecokelatan dan memiliki aroma yang khas. Daun sembung yang digunakan sebagai sampel pada penelitian ini dipetik di Kecamatan Abiansemal Kabupaten Badung Bali, yang dipetik pada bulan Maret 2017. Daun sembung dikeringkan selama 15 hari dengan rata-rata suhu pengeringan $\pm 28,60$ C. Cara pembuatan loloh sembung dilakukan dengan menggunakan air (Wita et al., 2014). Loloh sembung dibuat dengan formulasi $7 \%$ yang direbus selama 7 menit (Wita et al., 2016). Setelah proses perebusan dilakukan penyaringan untuk memisahkan antara loloh sembung dan ampas dari serbuk sembung. Kemudian dilakukan analisis proksimat untuk mengetahui kandungan gizi dari loloh sembung, analisis kandungan mineral natrium dan kalium pada loloh menggunakan metode SSA, dan dilakukan identifikasi GABA. Selain pada loloh, uji proksimat, analisa kadar natrium dan kalium, dan identifikasi GABA juga dilakukan pada daun sembung yang masih segar.

\section{Analisis Proksimat Daun Sembung dan Loloh Sembung}

Analisis proximat daun sembung meliputi uji kadar air, kadar abu, lemak, protein, dan karbohidrat ( metode by different). Hasil analisis proximat daun sembung dapat dilihat pada Tabel 5.2. Penentuan kadar air merupakan analisis penting yang harus dilakukan dalam pengolahan dan pengujian bahan pangan. Penentuan kadar air dalam penelitian ini menggunakan metode oven (Nielsen, 2010). Kadar air daun sembung segar dari hasil analisis adalah sebesar 83,8112\% bb sedangkan pada loloh sembung sebesar 99,2324 \% bb. Abu merupakan residu anorganik dari pembakaran bahan organik. Hasil analisis kadar abu dalam daun sembung segar 2,0617\% bb dan pada loloh sembung sebesar 0,0117 \% bb. Analisa kadar lemak sampel pada penelitian ini menggunakan metode soxhlet (Nielsen, 2010), pada daun sembung didapatkan hasil 2,850 \% bb. Penentuan kadar protein menggunakan metode kjeldahl (Nielsen, 2010), pada sampel daun sembung didapatkan kandungan protein sebesar $0,9659 \%$ bb. Kandungan karbohidrat pada daun sembung didapatkan hasil 10,3109\% bb (Tabel I)

Kadar abu pada daun sembung mengalami penurunan setelah menjadi loloh. Berdasarkan penelitian Andarwulan (2011) proses pengolahan dapat mengurangi ketersediaan mineral dalam bahan pangan terutama mineral yang larut air sehingga kadar abu menurun setelah pengolahan. Dibandingkan dengan daun sebagai antihipertensi lainnya seperti daun bayam merah (Amaranthus tricolor L.) yang memiliki kandungan gizi meliputi kadar air 92,65\%, kadar abu 0,62\%, protein 0,56 $\%$, lemak 0,12\%, karbohidrat 5,21\% (Amin et al., 2015) dan daun seledri (Apium graveolens) dengan kadar air 96,37\%, kadar abu 2,09\%, protein 0,92\%, lemak 0,11\%, dan karbohidrat $3,7 \%$ (Algirdas et al., 2012). Daun sembung memiliki kandungan karbohidrat lemak dan protein yang lebih tinggi dibandingkan dengan bayam merah dan daun seledri tetapi memiliki kadar air paling rendah. Kadar abu paling tinggi terdapat pada daun seledri dan teredah pada daun bayam merah.

\section{Kandungan Natrium dan Kalium}

Analisa kandungan natrium dan kalium pada sampel daun sembung dan loloh sembung dilakukan menggunakan metode SSA. Hasil analisa kandungan mineral natrium dan kalium 
Tabel I. Kandungan gizi daun sembung segar dan loloh sembung

\begin{tabular}{|c|c|c|c|c|c|}
\hline Sampel & Kadar Air (\% bb) & Kadar Abu (\% bb) & Protein (\% bb) & Lemak (\% bb) & Karbohidrat (\% bb) \\
\hline $\begin{array}{l}\text { Daun } \\
\text { Sembung }\end{array}$ & 83,8112 & 2,0617 & 0,9659 & 2,850 & 10,3109 \\
\hline $\begin{array}{l}\text { Loloh } \\
\text { Sembung }\end{array}$ & 99,2324 & 0,0117 & - & - & - \\
\hline
\end{tabular}

Tabel II. Kandungan natrium dan kalium daun sembung segar dan loloh sembung

\begin{tabular}{cccc}
\hline \multirow{2}{*}{ Sampel } & \multirow{2}{*}{ Satuan } & \multicolumn{2}{c}{ Hasil } \\
\cline { 3 - 4 } & & Natrium (Na) & Kalium (K) \\
\hline Daun Sembung & $\mathrm{mg} / \mathrm{L}$ & 579,72 & 7296,53 \\
Loloh sembung & $\mathrm{mg} / \mathrm{L}$ & 51,65 & 1353,19 \\
\hline
\end{tabular}

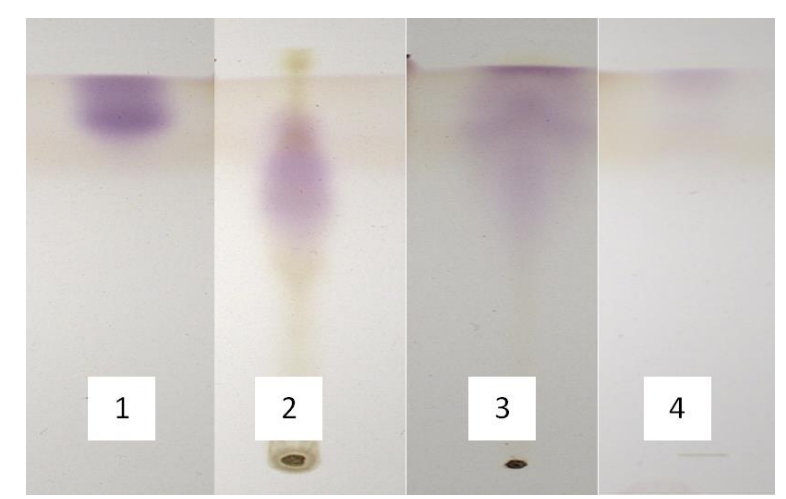

Gambar 1 Hasil Identifikasi GABA pada sinar tampak Standar GABA konsentrasi $10 \mu \mathrm{l}$ (1); daun sembung segar konsentrasi $10 \mu \mathrm{l}$ (2); loloh sembung konsentrasi $10 \mu \mathrm{l}$ (3); loloh sembung konsentrasi $5 \mu \mathrm{l}$

pada daun sembung segar dan loloh sembung (Tabel II). Terdapat perbedaan kandungan natrium dan kalium yang signifikan pada daun sembung segar dengan loloh sembung. Kandungan natrium dan kalium pada daun sembung yang telah diolah menjadi loloh lebih rendah dari daun sembung yang masih segar/belum diolah. Proses pengolahan yang dilakukan terhadap tanaman tertentu menurunkan konsentrasi mineral yang terkandung dalam tanaman. Perlakuan panas yang diberikan terhadap tanaman menyebabkan perubahan pada karakteristik tanaman serta mengurangi kandungan gizi. Sayuran yang diolah melalui proses perebusan atau pemanasan, mengalami perubahan karakteristik fisik dan komponen kimia (Hamazu et al., 2004). Penelitian ini juga didukung oleh Winarno (2008) yang menyatakan pengolahan bahan pangan dengan menggunakan suhu yang tinggi dapat menyebabkan terjadinya penguapan air pada bahan pangan tersebut, semakin tinggi suhu yang digunakan semakin banyak pula molekul-molekul air yang keluar dari permukaan bahan pangan, salah satu diantaranya mineral yang ikut terlarut bersama air. Berdasarkan hasil penelitian terhadap tanaman Hibiscus sabdariffa, juga terjadi penurunan kadar natrium dan kalium sebelum (segar) dan setelah diolah. Semakin lama waktu pengolahan kandungan natrium dan kalium semakin menurun (Musa and Ogbadoyi, 2012).

\section{Identifikasi GABA pada loloh sembung dan daun sembung segar}

Identifikasi GABA pada loloh sembung dan daun sembung segar menggunakan metode TLC. Dari hasil penelitian ditemukan kandungan GABA dalam sampel daun sembung segar dan sampel loloh sembung. Hasil TLC pada sampel diamati di bawah sinar dengan panjang gelombang $254 \mathrm{~nm}$ dan $366 \mathrm{~nm}$. Sampel juga diamati dengan menggunakan sinar tampak. Pada penelitian ini menggunakan air sebagai pelarut sampel daun sembung segar, loloh sembung dan standar GABA. pada penelitian ini sampel dan standar GABA ditotolkan dengan konsentrasi $5 \mu$ dan $10 \mu \mathrm{l}$. Penelitian ini tidak melalui proses spryimg/penyemprotan dengan nihdirin. Nihidrin langsung ditambahkan ke dalam fase gerak sehingga tidak dilakukan proses penyemprotan. 


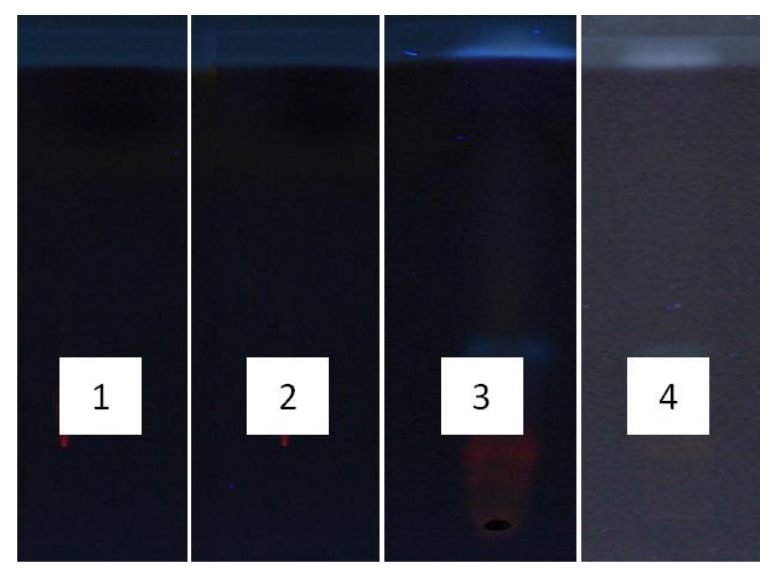

Gambar 2. Hasil Identifikasi GABA panjang gelombang $366 \mathrm{~nm}$ Standar GABA konsentrasi 10 $\mu \mathrm{l}(1)$; daun sembung segar konsentrasi $10 \mu \mathrm{l}$ (2); loloh sembung konsentrasi $10 \mu \mathrm{l}$ (3); loloh sembung konsentrasi $5 \mu \mathrm{l}(4)$

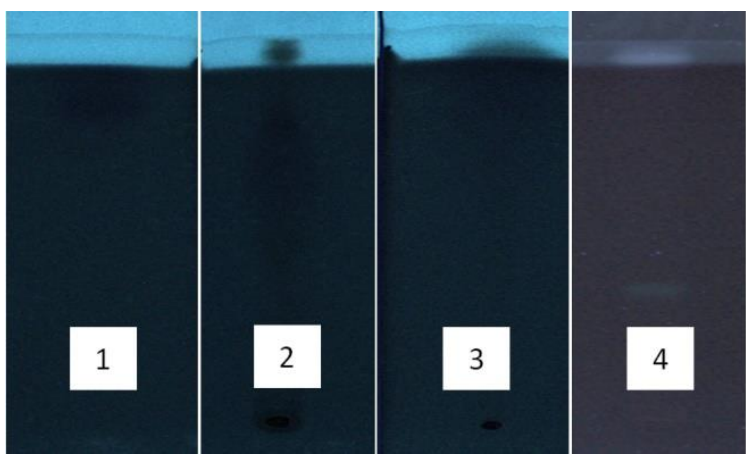

Gambar 3 Hasil Identifikasi GABA gelombang 254 nm Standar GABA konsentrasi $10 \mu \mathrm{l}$ (1); daun sembung segar konsentrasi $10 \mu \mathrm{l}$ (2); loloh sembung konsentrasi $10 \mu \mathrm{l}$ (3); loloh sembung konsentrasi $5 \mu \mathrm{l}(4)$

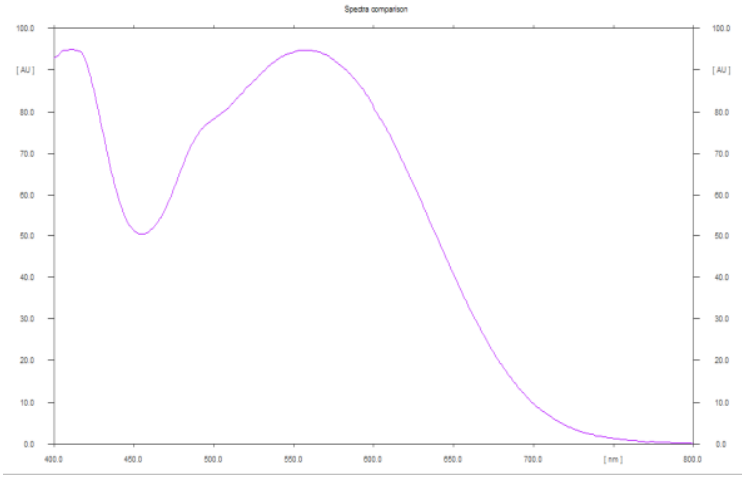

Gambar 4 Spektrum standar GABA

Fase gerak yang digunakan dalam penelitian ini sesuai dengan penelitian Qiu (2009) dengan perbandingan $\mathrm{n}$ butanol, asam asetat glasial dan air (5:3:2) dan ditambahkan nihidrin (Yogeswara et al., 2016). Hasil identifikasi GABA dengan metode TLC pada daun sembung segar dan loloh sembung (Gambar1, 2 dan 3) dan spektrum daun sembung serta spektrum standar GABA (Gambar 4 dan 5). Pada spektrum x merupakan panjang gelombang, y meupakan Rf.

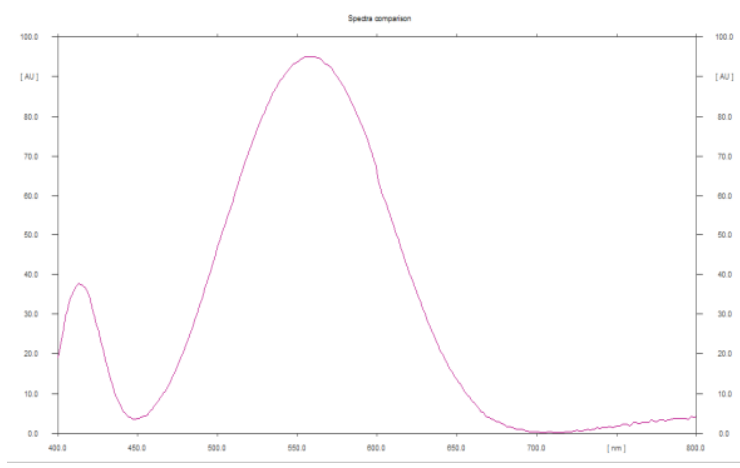

Gambar 5 Spektrum daun sembung

Pada penelitian identifikasi GABA pada daun sembung segar dan loloh sembung dengan menggunakan metode TLC dan air sebagai pelarut, sampel daun sembung segar dan loloh sembung ditotolkan masing-masing 1 kali dengan volume penotolan $5 \mu$ pada dan $10 \mu$ l. Larutan standar GABA ditotolkan 1 kali dengan volume penotolan $10 \mu \mathrm{l}$. Hasil penelitian ditemukan kandungan GABA pada daun sembung segar dan kandungan GABA pada loloh sembung, sehingga loloh sembung bisa dikonsumsi sebagai minuman fungsioal yang berpotensi sebagai antihipertensi. Hasil penelitian ini pada konsentrasi $10 \mu \mathrm{l}$ kandungan GABA dalam loloh sembung jelas terlihat sedangkan pada konsentrasi $5 \mu \mathrm{l}$ kandungan GABA dalam loloh sembung sangat sedikit dan tidak jelas terlihat.

Hasil penelitian menunjukkan pada daun Artocarpus altilis dengan menggunakan etanol $50 \%$ sebagai pelarut, terdapat kandungan GABA yang diidentifikasi dengan metode TLC (Indrowati et al., 2015). Berdasarkan penelitian juga terdapat kandungan GABA pada daun mulberi. Penelitian GABA pada daun mulberi menggunakan prosedur yang sama dengan penelitian ini, daun mulberi dikeringkan kemudian dibuat dalam bentuk serbuk dan dari hasil penelitian terdapat kandungan GABA pada daun (Yang et al., 2011)

\section{Potensi Loloh Sembung sebagai Minuman Antihipertensi}

Loloh sembung selain mengandung GABA yang berpotensi sebagai antihipertensi, juga tinggi kandungan flavonoid (Wita, et al., 2016) yang menurut penelitian berperan dalam meningkatkan volume urin (deuretik) dan mampu 
menghambat vasopressin yang telah diujicoba pada tikus dan terbukti dapat menurunkan tekanan darah (Ayu et al., 2015). Loloh sembung juga dapat menghambat Angiotensin Converting Enzym (ACE) (Wita et al. ,2017). Penghambat ACE digunakan sebagai pengobatan/terapi untuk antihipertensi (Santos et al., 2012) sehingga loloh sembung bisa digunakan sebagai minuman fungsional antihipertensi. Kandungan natrium dan kalium dari daun sembung segar menjadi loloh sembung mengalami penurunan sehingga bisa dikonsumsi sebagai minuman antihipertensi.

Hasil penelitian ini, daun sembung mengandung natrium 579,72 $\mathrm{mg} / \mathrm{L}$ dan kalium 7296,53 mg/L sedangkan loloh sembung mengandung natrium 51,65 mg/L dan kalium $1353,19 \mathrm{mg} / \mathrm{dL}$. Kandungan natrium dan kalium dari daun sembung menjadi loloh sembung mengalami penurunan, sehingga loloh sembung berpotensi dikonsumsi sebagi minuman fungsional antihipertensi karena kandungan natrium yang rendah. Hasil penelitian Sacks (2001) menunjukkan bahwa pengurangan asupan natrium pada diet sehari-hari dapat membantu menurunkan tekanan darah. Kalium memiliki korelasi hubungan yang negatif terhadap terjadinya hipertensi. Dietary Approaches to Stop Hyper-tension (DASH), diet yag kaya akan kandungan kalium yang banyak terdapat dalam buah-buahan, sayur-sayuran dan makanan olahan rendah lemak. Diet DASH terbukti dapat menurunkan tekanan darah pada penderita hipertensi

\section{KESIMPULAN}

Hasil penelitian identifikasi kandungan GABA dalam loloh sembung dan daun sembung segar dengan menggunakan metode TLC dapat disimpulkan. Nilai kandungan gizi loloh sembung meliputi kadar air 99,2324\%, kadar abu 0,0117 $\%$, dan daun sembung segar mengandung kadar air 83,8182 \%, kadar abu 2,0617 \%, protein $0,9659 \%$, lemak 2,850 \% dan karbohidrat $10,3109 \%$; Terdapat kandungan GABA pada daun sembung segar; Terdapat kandungan GABA pada loloh sembung.

\section{DAFTAR PUSTAKA}

Abe, Y., Umemura, S., Sugimoto, K.,Hirawa, N., Kato, Y., Yokoyama. (1995). Effect of Green Tea Rich in Gamma Aminobutyric Acid on Blood Pressure of Dahl salt-sesnsitive rats. American Journal of Hipertension, 8,74-79.

Akama, K., Kanetou,J., Shimosaki,S., Kawakami,K., Tsuchikura,S., \& Takaiwa, F. (2009). Seed spesific expression of truncate OsGAD2 produces GABA-enriched rice grains that influence a decrease in blood pressure in spontaneously hypertensive rats. Transgenic Research, 18, 865-876.

Akihiro,T., Koike,S., Tani, R., Tominaga,T., Watanabe,S., Iijima,Y., \& Ezura,H. (2008). Biochemical mechanism on GABA accumulation during fruit development in tomato. Plant and cell Physiology, 49 (9), 1378-1389.

Algridas, J., Januskevicience,G., Andruleviciute,V. (2012). Chemical Compostion and Energetic Values of Selected Vegetables Spicies in Lithuanian Supermarkets. Veterinarija Ir Zootechnika (Vet Met Zoot) 58 (80).

Amin, Md Zainul, Shariar,K., Sawraz,a.M., Satter,A. (2015) A Comparative Nutritional Analysis of Red Amarant (Amaranthus Tricolor L) on Refrigerating and nNn-Refrigerating Condition. International Journal of Green and Herbal Chemistry. Vol 4, No 3 243-255.

Aoki, H., Furuya, Y., Endo, Y., \& Fujimoto, K. (2003). Effect of gamma aminobutyric acidenriched tempeh-like fermented soybean (GABA-Tempeh) on the blood pressure of spontaneously hypertensive rats. Bioscience Biotechnology and Biochemisty, 67, 1806-1808.

Ayu Kusuma Wardani, I Gusti Agung., Ketut Agus Arianta. (2015). Efektivitas Ekstrak Etanol Daun Bayam Merah (Amaranthus tricolor) sebagai Deuretik pada Tikus Putih Jantan Galur Wistar (Rattus Hovergicus).

Duyff, RL. (2012). American Dietetic Association. Complete food and nutrition guld. Houghton miffle harcourt

Endrizzi, I., Pirretti, G., Calo,DG., Gaspen, F. (2009). A consumer study of fresh juice containing berry fruits. J.Sci Food Agric. 89 (7):12271235.

Hamauzu, Y. and Zhang, D. (2004). Phenolics, ascorbic acid, carotenoids and antioxidant activity of broccoli and their changes during conventional and microwave cooking. Food Chemistry, 88: 503-509.

Hayakawa, K, Kimura M, Kamata K. (2002). Mechanism Underlying gamma aminno butyric-acid -induced antihypertensive effect in spontaneously hypertensive rats. Eur.J.Pharmac.438,107-113.

Hayakawa,K., Kimura, M., \& Yamori, Y. (2005). Role of the renal nerves in gamma aminobutyric acid- induced antihypertensive effect in spontaneously hypertensive rats. European Journal of Pharmacology. 524.120-125 
Hayakawa,K., Kimura, M., Kasaha, K., Matsumoto, K., Sansawa, H., \& Yamori, Y. (2004). Effect of gamma aminobutyric acidenriched dairy product on the blood pressure of spontaneously hipertensive and normotensive wistar-Kyoto rats. British Journal of Nutrition,92, 411-417.

Indrowati,M., Pudji,A., Rarastoeti,P., Rumiyati. (2015). Deteksi Gamma-Aminobutyric Acid (GABA) Pada Daun Artocarpus Altilis. Seminar Nasional Pendidikan Sains FIKP UNS.

Joint National Commitee (JNC). (2003). Prevention, Detection, Evaluation, and Treatment of High Blood Pressure. US Departemnet of Health dan Human Service.

Kimura, M., Hayakawa, K., \&Sansawa, H. (2002). Involvement of gamma aminobutyric acid (GABA) $B$ receptors in the hypotensive effect of systemically administered GABA in spontaneously hypertensive rats. The Japanese Journal of Pharmacology, 89,388394.

Musa, A dan Ogbadoyi, E.O. (2012). Effect of Processing Methods on some Micronutrients, Antinutrients and Toxic Substance in Hibicus sabdariffa. Asian Journal of Biochemistry. 7 (2) : 63-79.

Nathalie, Lisbeth Leurs. 2009. Medical, Aromatic, and Cosmetic (MAC) Plants for Community Health and Bio-Cultural Diversity Conservation in Bali, Indonesia. L.N. Leurs page $124: 127$

Nielsen, S.S. (2010). Food analysis laboratoty manual. Department of Food Science. Purdue University West Lafayette. IN USA

Norikura, T., Kojima, Y.A., Shamizu,M., Huang. X.Xu, S., Kametami, S., Rho, SN., Kennedy, D.O., and Matsui, Y.I. (2008). Anticancer activities and mechanism of Blumea balsamifera exctract in hepatocellular carsinoma cells. Am J Chib Med. 36 (2):41124

Qiu, T., Li,H., \& Cao, Y. (2009). Pre-staining thin layer chromatography method for amino acid detection Afr J Biotechnol, 9, 8679-8681

Riset Kesehatan Dasar. (2013) Penyakit tidak menular. Halaman : 121-136

Sacks,F.M., Laura,F.S., Willia,M.V., lawrence,S.R., George,A.B., David,H., Eva,O., Paul,R.C., Edgar,R.M., Denise,G.S.M., Njeri,K., PaoHwa,L., Mikel,A., Marlene,M.M.W.,
Thomas,J.M., Michael,A.P., Jettrey,A.C. (2001). Effect of Blood Pressure of Reduce Dietary Sodium and The Dietary Approach to Stop Hypertension (DASH) Diet. The New England Journal of Medicine. 344 : 310.

Santos, P.C.J.L., Krieger, J.E., and Pireira, A.C. (2012). Renin agiotensin system hypertension and chronic disease. Pharmacogenetic implication Journal of Pharmacological science, 120:77-78.

sembung (Blumea balsamifera).

Winarno, F.G. (2008). Kimia Pangan dan Gizi. Bogor : Mrio Press.

Wita, I.G.A., Darmawijaya, I Putu., Yogeswara, I.B.A., Santoso, U., Marsono, Y. (2016). Formulasi dan kemampuan menangkal radikal bebas dari loloh

Wita, I.G.A., I.M Wisnu A.P., Yogeswara, I.B.A., Santoso, U., Marsono, Y. (2016). Antioxidannt and antihypertensive activity of loloh sembung (Blumea balsamifera). Traditional Medecine Journal. Vol 2. No 3.

Wita, I.G.A., Yogeswara, I.B. (2016). Antioxidant and Antibacterial Capacity of Loloh Sembung (Blumea balsamifera) based on Extraction Method. Trad.Med.J. Vol. 21 (3). Page 143-148.

Wita, I.G.A.,Darmawijaya, I Putu ., \& Yogeswara, I.B.. 2014. Potensi aktioksidan loloh tempuyung (Sonchus arvensis L.) sebagai minuman fungsional. Prosiding Seminar Nasional Biologi FMIPA UNHI

Yamakoshi,J., $\quad$ Fukuda,S., Satoh, T., Tsuji R., Saito M. (2007). Antihypertensive and natriuretic effect of less sodium soy sauce containing gamma aminobutyric acid in spontaneously hipetensive rats. Bioscience Biotechnology and Biochemisty, 71, 165-173

Yang,N.C., Kun,Y.J., Chin,Y.T. (2012). Antihypertensive Effect of Mulberry Leaf Aqueous Extract Containing $r$ Aminobutyric Acid in Spontaneously Hypertensive Rats. Food Chemistry 132.1796-1801

Yogeswara, I.B.A., Sumadewi, U., Rahayu, E., Indrati, R. 2017. Isolasi dan Skrining Bakteri Asam ` Laktat Isolat Asam rAminobutirat. Abstrak.

Yoshimura,M., Toyoshi,T., Sano,A., Izumi,T., Fujii,T., Konishi,C. (2010). Antihypertensive effect of gamma amiobutyric acid rich tomato cultiver 'DG03-9' in 